\title{
Ag43-mediated display of a thermostable $\beta$-glucosidase in Escherichia coli and its use for simultaneous saccharification and fermentation at high temperatures
}

\author{
Iván Muñoz-Gutiérrez ${ }^{1,2}$, Cessna Moss-Acosta' ${ }^{1}$, Berenice Trujillo-Martinez ${ }^{1}$, Guillermo Gosset ${ }^{1}$ \\ and Alfredo Martinez ${ }^{1 *}$
}

\begin{abstract}
Background: The autotransporter (AT) system can potentially be used in the secretion of saccharolytic enzymes for the production of lignocellulosic biofuels and chemicals using Escherichia coli. Although ATs share similar structural characteristics, their capacity for secreting heterologous proteins widely varies. Additionally, the saccharolytic enzyme selected to be secreted should match the cell growth or cell fermentation conditions of $E$. coli.

Results: In the search for an AT that suits the physiological performance of the homo-ethanologenic E. coli strain MS04, an expression plasmid based on the AT antigen 43 (Ag43) from E. coli was developed. The $\beta$-glucosidase BglC from the thermophile bacterium Thermobifida fusca was displayed on the outer membrane of the E. coli strain MS04 using the Ag43 system (MS04/pAg43BglC). This strain was used to hydrolyze and ferment $40 \mathrm{~g} / \mathrm{L}$ of cellobiose in mineral media to produce $16.65 \mathrm{~g} / \mathrm{L}$ of ethanol in $48 \mathrm{~h}$ at a yield of $81 \%$ of the theoretical maximum. Knowing that $\mathrm{BglC}$ shows its highest activity at $50^{\circ} \mathrm{C}$ and retains more than $70 \%$ of its activity at pH 6, therefore $\mathrm{E}$. coli MS04/ pAg43BglC was used to ferment crystalline cellulose (Avicel) in a simultaneous saccharification and fermentation (SSF) process using a commercial cocktail of cellulases (endo and exo) at $\mathrm{pH} 6$ and at a relatively high temperature for E. coli $\left(45^{\circ} \mathrm{C}\right)$. As much as $22 \mathrm{~g} / \mathrm{L}$ of ethanol was produced in $48 \mathrm{~h}$.

Conclusions: The Ag43-BglC system can be used in E. coli strains without commercial $\beta$-glucosidases, reducing the quantities of commercial enzymes needed for the SSF process. Furthermore, the present work shows that $E$. coli cells are able to ferment sugars at $45^{\circ} \mathrm{C}$ during the SSF process using $40 \mathrm{~g} / \mathrm{L}$ of Avicel, reducing the gap between the working conditions of the commercial saccharolytic enzymes and ethanologenic $E$. coli.
\end{abstract}

Keywords: Ethanologenic Escherichia coli, Simultaneous saccharification and fermentation, Cellulose, Autotransporter Ag43, Thermobifida fusca $\beta$-glucosidase, Ethanol

\section{Background}

The approaching exhaustion of abundant, inexpensive oil and the pollution produced by burning fossil fuels are both factors that are driving research to explore environmentally friendly renewable fuels [1]. Different sugar sources can be transformed by fermentation processes into liquid biofuels, such as bioethanol, that can

\footnotetext{
* Correspondence: alfredo@ibt.unam.mx

'Departamento de Ingeniería Celular y Biocatálisis, Instituto de Biotecnología, Universidad Nacional Autónoma de México, A. P. 510-3, 62250 Cuernavaca, Mor, México

Full list of author information is available at the end of the article
}

be used, after distillation and dehydration, in current internal combustion engines [1]. Lignocellulose, the most abundant biopolymer on earth, represents a source of fermentable sugars that does not compete with the production of foodstuffs. The transformation of lignocellulose into ethanol fuel consists of several steps: 1) pretreatment of the biomass to reduce the crystallinity of the cellulose, to eliminate a fraction of the lignin and to hydrolyze part of the sugars contained in the hemicellulosic fraction, 2) enzymatic hydrolysis of the pretreated material to depolymerize most of the cellulosic fraction, 
3) fermentation of the released mixture of sugars, and 4) ethanol purification [2]. To simplify the production process and reduce costs, enzymatic hydrolysis and fermentation can be performed in a single reactor (simultaneous saccharification and fermentation (SSF)). The SSF process reduces the number of reactors needed and avoids the end product inhibition of cellulases [3].

The hydrolysis of lignocellulose produces a wide variety of fermentable sugars, such as hexoses, pentoses and uronic acids, and a capable microorganism is required to ferment all of these sugars. Escherichia coli has this ability, and has been metabolically engineered to create homo-ethanologenic version of this bacterial strain [4-7]. Although it is possible to perform the SSF process with pretreated lignocellulose using $E$. coli, the major drawback is that commercial enzymes and $E$. coli are incompatible in terms of their working conditions. While commercial enzymatic cocktails work at $\mathrm{pH} 5$ and $50^{\circ} \mathrm{C}$ [8], E. coli grows at $\mathrm{pH} 7$ and $37^{\circ} \mathrm{C}$. As a consequence, a balance in the $\mathrm{pH}$ and temperature must be found. In a recent report, our research group showed the ability of the ethanologenic E. coli strain MS04 [5] to ferment pretreated corn stover in a SSF process that occurred at $37^{\circ} \mathrm{C}$ and $\mathrm{pH} 6$ [9], reducing the gap between the saccharification conditions of commercial saccharolytic enzymes and the fermentation conditions of $E$. coli. Although ethanologenic E. coli MS04 showed good compatibility and performance with the commercial cocktail of cellulases, it is necessary to reduce the amount of externally added enzymes during the SSF process [10]. To achieve this reduction, $E$. coli must be engineered to secrete saccharolytic enzymes. In this regard, the cell surface display of enzymes involved in the depolymerization of low-cost polysaccharides is attracting much attention [10].

One option for cell surface display in E. coli is the type $\mathrm{V}$ secretion system, also known as the autotransporter (AT) system. ATs are multidomain proteins consisting of a signal peptide (SP), a passenger protein and a translocation unit (TU). The TU consists of a linker region and a $\beta$-barrel $[11,12]$. The linker region anchors the passenger protein to the cell surface. However, some ATs process the linker region after the passenger protein is translocated across the outer membrane, releasing the passenger protein into the milieu; it can also remain strongly associated with the TU $[11,12]$. To display a heterologous protein with the AT system, the DNA sequence of the native passenger protein is replaced by the heterologous sequence [11]. The relative simplicity of the AT system makes it potentially useful for the secretion of saccharolytic enzymes in E. coli strains engineered for the production of biocommodities [10]. Nevertheless, there are only a few reports that show that the secretion of saccharolytic enzymes is possible using the AT system with this bacterium [13,14]. Although the
ATs share similar structural characteristics, their capacity for secreting heterologous proteins varies widely depending on the genetic background of the $E$. coli strain that is used [15-18]. Additionally, the performance of the cell surface display can be affected by the composition of the media, the presence of proteases, the temperature and the cultivation technique used, among other factors [15]. As a consequence, it is important to find an AT that can be adapted to specific conditions. Gram-negative bacteria have seven specialized protein secretion systems (types I to VI and the chaperoneusher pathway) that allow secreted proteins to travel through the inner and outer membrane [12]. Autotransporters are a superfamily of proteins that use the type $\mathrm{V}$ secretion pathway for the delivery of proteins to the surface of Gram-negative bacteria [12]. A bioinformatics study performed by Wells et al. in 2010 [19], with twenty-eight Escherichia coli genomes, revealed that $E$. coli has 215 autotransporter-encoding sequences.

In this work, in the search for an AT that suits the genetic background and physiological performance of the ethanologenic E. coli MS04 strain, we constructed an expression plasmid based on the AT antigen 43 (Ag43) from E. coli [20]. To facilitate the cloning of any gene encoding a saccharolytic enzyme, we introduced a multiple cloning site between the SP and the TU of Ag43. The $\beta$-glucosidase BglC from the thermophile bacterium Thermobifida fusca [21], an enzyme that possesses a high robustness when secreted in E. coli [13,22-24], was displayed using the Ag43 system. Taking advantage of the fact that $\mathrm{BglC}$ shows its highest activity at $50^{\circ} \mathrm{C}$ and retains more than $70 \%$ of its activity at $\mathrm{pH} 6$ [21], E. coli MS04 expressing the Ag43-BglC system was used to ferment crystalline cellulose (Avicel) in an SSF process with a commercial cocktail of cellulases at $\mathrm{pH} 6$ and at a relative high temperature for $E$. coli $\left(45^{\circ} \mathrm{C}\right)$. The present work shows that the Ag43-BglC system can be used in ethanologenic $E$. coli strains to avoid the use of commercial $\beta$-glucosidases, reducing the amount of commercial enzymes used during SSF processes. Further, it shows that ethanologenic E. coli cells can be used to ferment sugar mixtures at $45^{\circ} \mathrm{C}$.

\section{Results}

\section{Construction of the Ag43 display system}

Figure 1 shows the domain organization of Ag43 and depicts the structure of the developed plasmids pAg43pol and pAg43BglC. The Ag43 domains and the relevant restriction sites used during plasmid construction are shown. The pTrc99A2 plasmid (Table 1), which contains the IPTG-inducible trc promoter, was used as the backbone of the Ag43-based secretion system. During the construction of the pAg43pol plasmid, the RfluBNE and DfluKXB primers inserted the unique restriction 


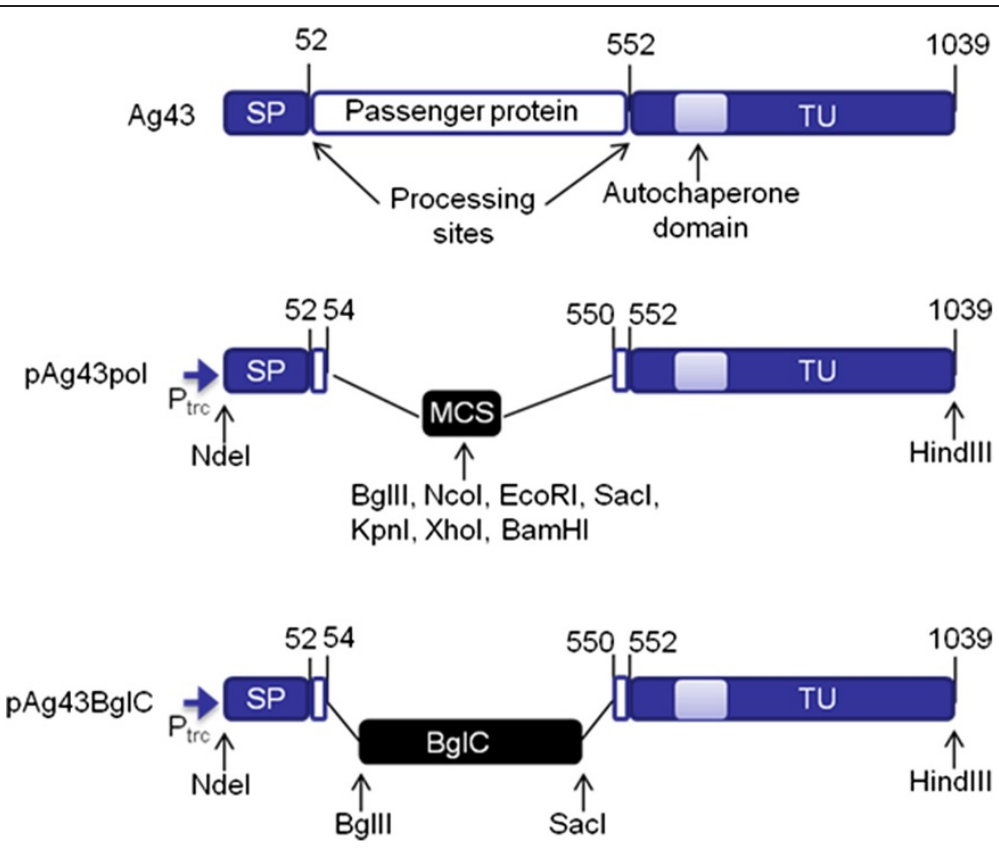

Figure 1 The arrangement of the protein domains of Ag43 and an overview of the Ag43-based secretion systems developed in this study (drawing is not to scale). The numbers designate the amino acids at the domain boundary. The restriction sites used for plasmid construction are indicated. SP, signal peptide; TU, translocation unit; $P_{\text {trc }}$ promoter trc; MCS, multiple cloning site; BglC, T. fusca $\beta$-glucosidase.

Table 1 E. coli strains, plasmids and primers used in this study

\begin{tabular}{|c|c|c|}
\hline Strain & Relevant genotype & Source \\
\hline E. coli DH5a & $\operatorname{Rec} A$ & Promega \\
\hline $\begin{array}{l}\text { E. coli } \\
\text { MG1655 }\end{array}$ & Wild type & $\begin{array}{l}\text { Laboratory } \\
\text { stock }\end{array}$ \\
\hline E. coli MSO4 & MG1655 $\Delta p f \mid B, \Delta a d h E, \Delta f r d A, \Delta x y / F G H$, gatC S184L, $\Delta$ midarpA, $\Delta r e g 27.3$ kb, $\Delta / d h A, P p f i B: . p d c_{Z m}-a d h B_{Z m}$. & {$[5,28]$} \\
\hline $\begin{array}{l}\text { E. coli BL21 } \\
\text { (DE3) }\end{array}$ & $\mathrm{F}^{-}$ompT hsdS $\left(r_{B}^{-} m_{B}^{-}\right) \mathrm{gal} d \mathrm{~cm}(\mathrm{DE} 3)$ & Novagen \\
\hline Plasmid & Description & Source \\
\hline pTrc99A2 & $\begin{array}{l}\text { pTrc99A derivative modified for Ndel cloning instead of Ncol. Designed for IPTG-inducible expression of proteins under } \\
\text { the hybrid trp/lac promoter. Ampr. }\end{array}$ & [13] \\
\hline pAIDABgIC & pTrc99A derivative designed for cell surface display of BglC using the autotransporter AIDA-I. Ampr. & [13] \\
\hline pET-22b(+) & Designed for IPTG-inducible expression of proteins under the T7 promoter. Ampr. & Novagen \\
\hline pETflu & pET-22b(+) derivative that has cloned the flu gene. & This study \\
\hline pAg43pol & $\begin{array}{l}\text { pTrc99A derivative designed for cloning heterologous sequences for protein secretion using the } \\
\text { autotransporter Ag43. Ampr. }\end{array}$ & This study \\
\hline pAg43BglC & pAg43pol derivative designed for cell surface display of BglC using the autotransporter Ag43. Ampr. & This study \\
\hline pNS6 & pET-26b(+) derivative employed for intracellular heterologous production of BglC in E. coli. & [21] \\
\hline aPrimer & Sequence $5^{\prime} \rightarrow 3^{\prime}$ & Source \\
\hline DfluNde & CTAAGGAAAAGCATATGAAACGACATCTG & This study \\
\hline RfluHind & CAGAGAGGCGAAGCTTCTGTCAGAAGGTC & This study \\
\hline Pet38F (26) & CGATCTCGATCCCGCGAAATTAATAC & This study \\
\hline RfluBNE & CGGTGAATTCCGCCATGGCAGATCTGTCAGCAGCCAGCACCGGGAG & This study \\
\hline DfluKXB & GACCGGTACCCTCGAGCTGAACGGATCCATTGACCCCACG & This study \\
\hline
\end{tabular}

${ }^{a}$ The restriction sites employed during plasmid construction are underlined. 
enzyme sequences $B g l \mathrm{II}, N c o \mathrm{I}, E c o R \mathrm{I}, K p n \mathrm{I}, X h o \mathrm{I}$ and $B a m H I$, creating multiple cloning sites between the SP and the TU. The pAg43pol plasmid contains the native Ag43 SP and the sequence that encodes amino acids 550 through 1039 of Ag43, including the TU and the autochaperone domain [20]. Whereas some ATs designed for the display of heterologous proteins replace the native SP, such as the widely used AIDA-I system developed by Maurer et al. [16], the pAg43pol plasmid contains the native Ag43 SP. Some ATs, such as Ag43, have unusually long SPs that likely slow the translocation of the ATs across the inner membrane, preventing the accumulation of misfolded proteins in the periplasmic space [12]. To avoid cleavage at amino acid 552 and keep the heterologous passenger protein attached to the cell surface, the aspartyl protease active site present in the Ag43 passenger protein [25] was not included. To display BglC on the surface of E. coli MS04, the $b g l C$ gene was cloned into pAg43pol to obtain pAg43BglC as described in the Methods section.

\section{Whole-cell protease treatment analysis}

Proteins that are attached and exposed externally on the cell surface of $E$. coli can be removed from whole cells using proteases. After proteolytic treatment, outer membrane proteins (OMPs) can be purified and analyzed using SDS-PAGE, at which point little or no cell surface proteins will be observed. To show that $\mathrm{BglC}$ is exposed externally on the cell surface of MS04, whole cells expressing the Ag43-BglC system were treated with trypsin as reported previously [13]. Cells carrying pTrc99A2 were used as a negative control. After their growth, the cells were harvested and "shaved" with trypsin, and the OMPs were subjected to purification. The calculated molecular weight of the chimeric protein Ag43-BglC without the SP is $106 \mathrm{kDa}$ (thus, it was named P106). Figure 2 shows a polyacrylamide gel with the OMPs purified from both trypsin-treated and untreated cells. It can be observed that, in contrast with the negative control, the cells carrying the $\mathrm{pAg} 43 \mathrm{BglC}$ plasmid that were not trypsinized possessed the protein P106. When the cells were treated with trypsin, the protein P106 content is drastically reduced, showing that the Ag43 system attaches BglC to the surface of E. coli MS04. In previous work involving the AIDA-BglC system [13], we performed both SDS-PAGE and western blot analyses of the outer membrane proteins and, as with the Ag43BglC system, the SDS-PAGE clearly showed the identity of the fusion protein.

\section{Fermentation of glucose, cellobiose and cellulose}

E. coli MS04 expressing the Ag43-BglC system was tested for the hydrolysis and fermentation of $40 \mathrm{~g} / \mathrm{L}$ glucose or $40 \mathrm{~g} / \mathrm{L}$ cellobiose in mineral media. Figure 3 shows cell

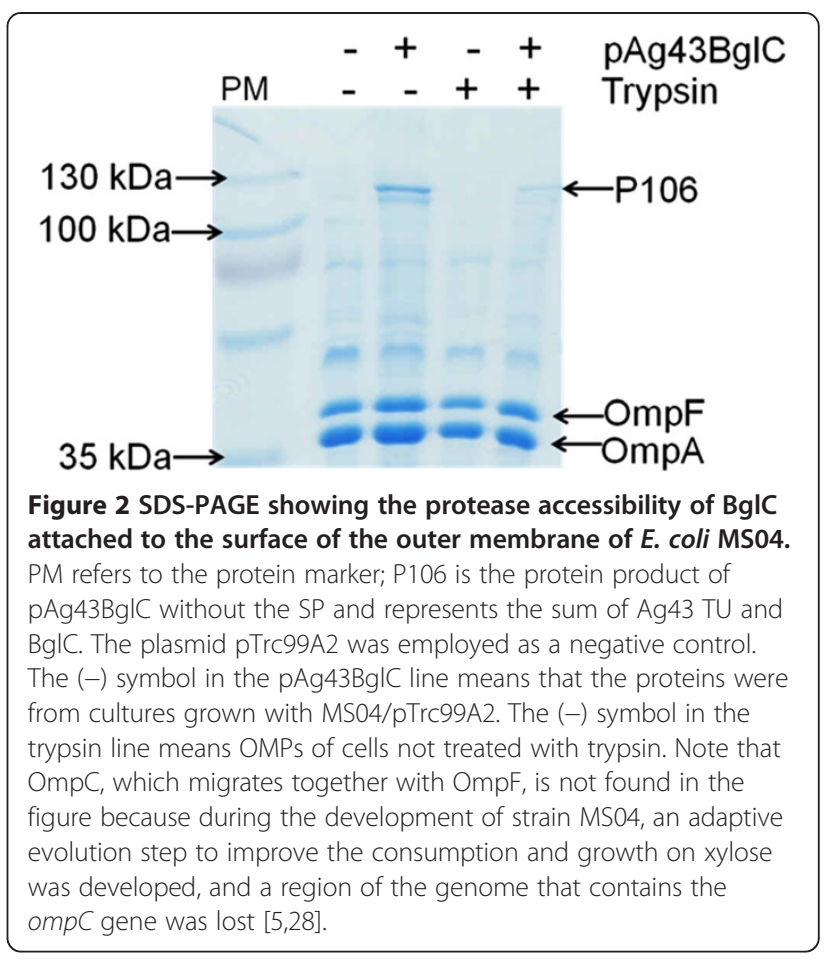

growth, glucose or cellobiose consumption and ethanol production during the fermentation processes. E. coli MS04/pAg43BglC had a specific growth rate $(\mu)$ of $0.276 \mathrm{~h}^{-1}( \pm 0.005)$ in glucose and $0.153 \mathrm{~h}^{-1}( \pm 0.004)$ in cellobiose; it consumed the glucose in $24 \mathrm{~h}$ and the cellobiose in $48 \mathrm{~h}$ and reached a titer of ethanol of $14.94 \mathrm{~g} / \mathrm{L}$ $( \pm 0.64)$ with glucose and $16.65 \mathrm{~g} / \mathrm{L}( \pm 0.23)$ with cellobiose. The obtained ethanol yields were $80 \%( \pm 3.2)$ and $81 \%$ $( \pm 2.6)$ of the theoretical maxima in glucose and cellobiose, respectively. During the fermentation of cellobiose, the $\beta$ glucosidase activities, either that present in the milieu or that was cell-associated, were measured at $37^{\circ} \mathrm{C}$ when the cells reached an $\mathrm{OD}_{600}$ of 1 ; values of $6.05 \mathrm{U} / \mathrm{L}( \pm 0.88)$ and $59.6 \mathrm{U} / \mathrm{g}_{\mathrm{DCW}}( \pm 4)$ were obtained, respectively. The cell-associated activity represents $79 \%$ of the total activity, taking into account that $1 \mathrm{OD}_{600}$ of cells is equal to 0.37 $\mathrm{g}_{\mathrm{DCW}} / \mathrm{L}$.

To show the compatibility of the displayed $\mathrm{BglC}$ with a commercial cocktail of cellulases and the capacity of $E$. coli MS04 to ferment at working conditions that can match these cellulases, E. coli MS04 expressing the Ag43$\mathrm{BglC}$ system was tested in the SSF process with $40 \mathrm{~g} / \mathrm{L}$ crystalline cellulose (Avicel) and the cellulase cocktail Celluclast (15 FPU/g Avicel of cellulases) at a temperature of $45^{\circ} \mathrm{C}$ and $\mathrm{pH} 6$. Control experiments were performed using E. coli MS04/pTrc99A2 with Celluclast, E. coli MS04/pTrc99A2 with Celluclast and the $\beta$-glucosidase cocktail NS50010 (30 U/g Avicel of $\beta$-glucosidase) and $E$. coli MS04/pTrc99A2 with Celluclast and soluble T. fusca $\mathrm{BglC}(30 \mathrm{U} / \mathrm{g}$ Avicel of $\beta$-glucosidase produced from $E$. 

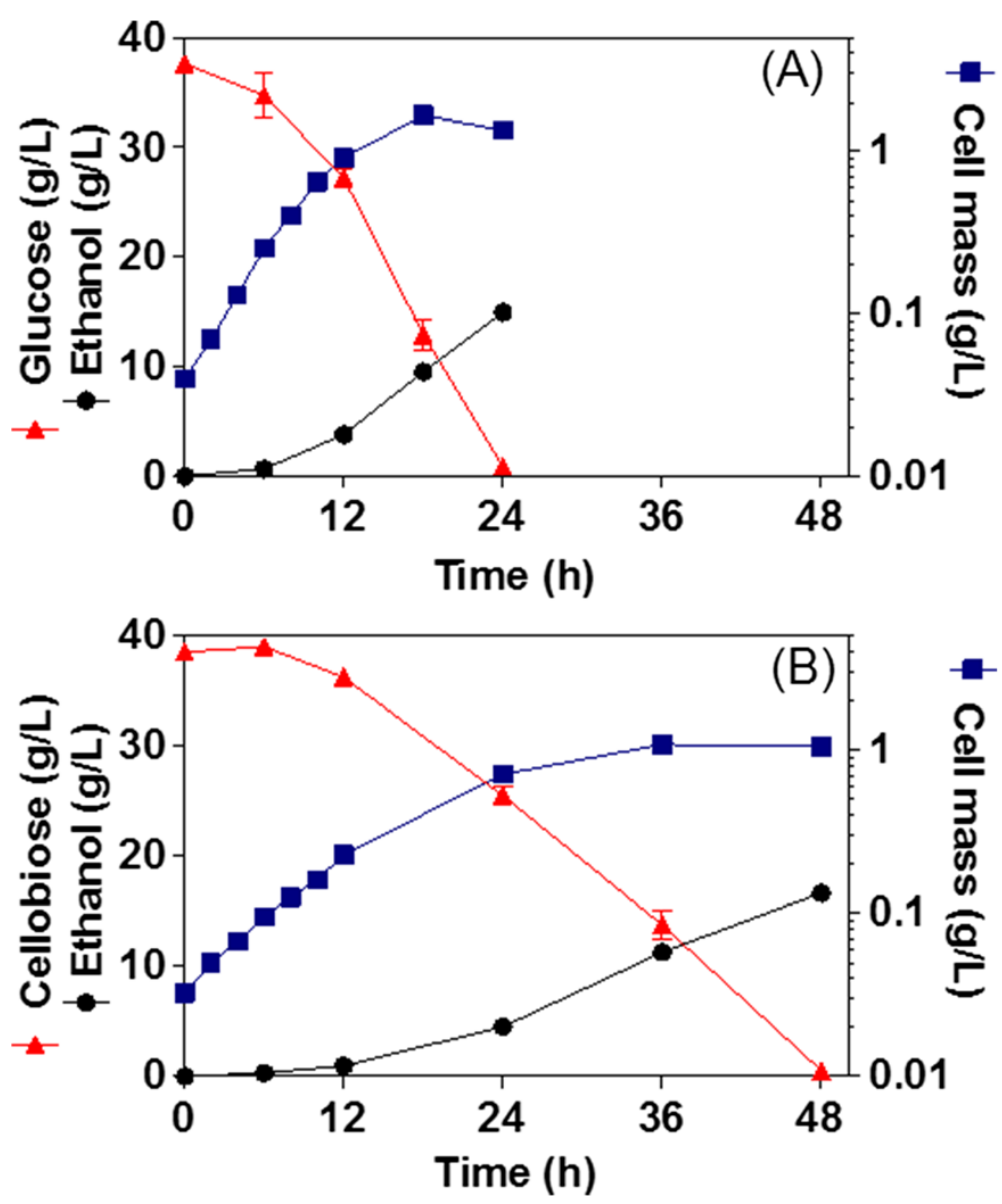

Figure 3 Fermentation kinetics of glucose (A) and cellobiose (B) with MS04/pAg43BglC. Cultures were performed at $37^{\circ} \mathrm{C}$ and $\mathrm{pH} 7(\mathrm{n}=4)$.

coli BL21 carrying plasmid pNS6, as mentioned in the Methods section). The ethanol production during the SSF of Avicel is shown in Figure 4. The highest titers of ethanol (approximately $22 \mathrm{~g} / \mathrm{L}$ ) were reached after $48 \mathrm{~h}$ of fermentation using MS04/pAg43BglC supplemented with Celluclast and the control MS04/pTrc99A2 supplemented with Celluclast and T. fusca BglC. The lowest titers of ethanol (approximately $15 \mathrm{~g} / \mathrm{L}$ ) were obtained using MS04/pTrc99A2 supplemented with Celluclast and MS04/pTrc99A2 supplemented with Celluclast and NS50010. It is interesting that the commercial cocktail of $\beta$-glucosidases (NS50010) did not improve the SSF process at the conditions tested. During the preparation of the inoculum for the SSF, E. coli MS04/pAg43BglC had an activity of $10.4 \mathrm{U} / \mathrm{DO}$ (measured at $45^{\circ} \mathrm{C}$ and $\mathrm{pH}$ 7).

\section{Discussion}

The AT system has been extensively used for the heterologous display of proteins in E. coli [11]; however, the secreting capacities of heterologous proteins in ATs vary widely depending on the genetic background of the strain used [15-18] and the culture conditions [15]. Among ATs, Ag43 is a promising secretion system because it is able to translocate folded passenger proteins. Additionally, the outer membrane protease OmpT does not have a negative effect on the display of the passenger protein $[17,18]$. To determine the potential of the display system Ag43 in the genetic background of the ethanologenic E. coli MS04, we constructed the expression plasmid pAg43pol, which contains multiple cloning sites between the SP and the TU and allows for the easy cloning of genes encoding saccharolytic enzymes or other proteins (Figure 1).

The secretion of $\beta$-glucosidases by ethanologenic microorganisms during cellulosic biofuel production allows the addition of commercial $\beta$-glucosidases to be avoided, reducing production costs. It is critical to select saccharolytic enzymes to be secreted by $E$. coli that have working conditions that match the growth conditions of the E. coli. In addition, the selected $\beta$-glucosidases must be expressed with enough activity to allow the growth of the cells and the fermentation on cellobiose [13,22-24]. The $\beta$-glucosidase selected for secretion was $\mathrm{BglC}$ from 


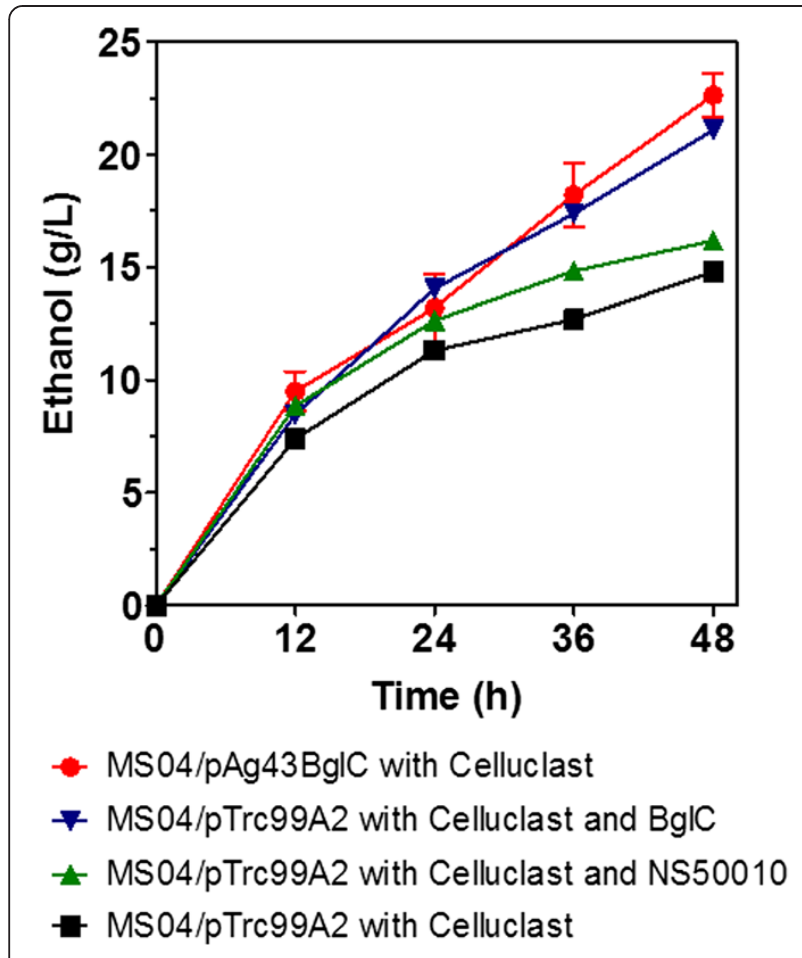

Figure 4 Ethanol production during the SSF process of $40 \mathrm{~g} / \mathrm{L}$ Avicel by MS04 carrying plasmid pAg43BglC or pTrc99A2.

These cultures were performed at $45^{\circ} \mathrm{C}$ and $\mathrm{pH} 6(n=3)$.

T. fusca [21], an enzyme that presents a high performance compared with other $\beta$-glucosidases that have been secreted by E. coli $[22,24]$. For example, of the six different $\beta$-glucosidases studied by Tanaka et al. [24] and the three different $\beta$-glucosidases studied by Desai et al. [22], BglC from T. fusca was either the sole $\beta$-glucosidase to allow the growth of $E$. coli using cellobiose as the sole carbon source or the one that promoted the highest growth. In the present work, we show that the AT Ag43 is able to display BglC on the surface of the ethanologenic E. coli strain MS04 (Figure 2) and that the enzyme that is attached is catalytically active ( $E$. coli MS04 expressing the Ag43-BglC system fermented cellobiose as the sole carbon source in mineral media) (Figure 3B). Although BglC activity was observed in the supernatant, most of it was cell associated (79\%); this result is important because in the SSF process wholecell biocatalysts are produced and recovered for subsequent hydrolysis and fermentation. The Ag43 system is more efficient for the secretion of $T$. fusca $\beta$-glucosidase BglC compared with the AIDA-I system [13]. E. coli MS04 expressing the Ag43-BglC system had a $24 \%$ higher cell-associated $\beta$-glucosidase activity, fermenting $40 \mathrm{~g} / \mathrm{L}$ cellobiose in $48 \mathrm{~h}$ instead of $72 \mathrm{~h}$ as with the AIDA-BglC system. When grown on cellobiose, E. coli MS04 expressing the Ag43-BglC system had a $\mu$ that was $21 \%$ higher than that obtained with MS04 expressing the AIDA-BglC system [13].

In the present report, we show the suitability of the Ag43-BglC secretion system for SSF processes employing E. coli and commercial cellulases. In Figure 4, it is clear that E. coli MS04 expressing the secretion system Ag43-BglC performed better during the SSF of crystalline cellulose compared to cells carrying the empty plasmid that were supplemented with commercial $\beta$-glucosidases. It is important to note that the SSF process was carried out at $45^{\circ} \mathrm{C}$ and $\mathrm{pH} 6$, conditions that allow for both the cellulase cocktail and BglC to perform better. The activities of the $\beta$-glucosidases present in the commercial cocktails are severely affected by both $\mathrm{pH}$ and temperature $[26,27]$. These results show that commercial $\beta$-glucosidases do not need to be used with the Ag43-BglC system during SSF processes with ethanologenic E. coli.

\section{Conclusions}

The selection of the right secretion system and saccharolytic enzymes is crucial during the engineering of $E$. coli. In the present work, we show that the AT Ag43 can be used to successfully secrete the $\beta$-glucosidase $\mathrm{BglC}$; better results were obtained than when the previously reported AT system AIDA-BglC was used. Additionally, most of the $\beta$-glucosidase activity obtained with the Ag43-BglC system was cell-associated, allowing the recovery of the whole-cell biocatalyst for subsequent SSF processes. Finally, the feasibility of performing SSF at a relatively high temperature for $E$. coli was shown using commercial cellulases and $40 \mathrm{~g} / \mathrm{L}$ of Avicel. Cells from the strain MS04/pAg43BglC were able to produce $22 \mathrm{~g} / \mathrm{L}$ of ethanol at $45^{\circ} \mathrm{C}$ and $\mathrm{pH} 6$, reducing the gap between the working conditions of the commercial saccharolytic enzymes and ethanologenic E. coli.

\section{Methods}

\section{Strains and plasmids}

The strains, plasmids and primers used in this study are listed in Table 1. E. coli DH5 $\alpha$ was used for plasmid propagation during plasmid construction. Analyses of $\beta$-glucosidase secretion and ethanol fermentation were performed using the E. coli strain MS04 [5,28]. Standard procedures were employed for DNA isolation, PCR, restriction-enzyme digestion, cloning, ligation, transformations, and gel electrophoresis experiments [29]. Polymerase chain reaction (PCR) experiments were performed using the Elongase Enzyme Mix (Invitrogen, Carlsbad, CA, USA). Restriction enzymes and ligases were purchased from Fermentas (Thermo Fisher Scientific Inc., MA, USA). PCR and agarose-gel products were isolated and purified using the High Pure PCR Product Purification Kit (Roche, Mannheim, Germany). Each plasmid construction was verified by 
its restriction pattern in an agarose gel and via sequencing. Primer synthesis and DNA sequencing were performed by the Core Unit of Synthesis and Sequencing of DNA at the Biotechnology Institute-UNAM.

The $f l u$ gene sequence, which encodes Ag43, was PCR-amplified using the DfluNde and RfluHind primers (Table 1); genomic DNA from E. coli MG1655 was used as the template. The PCR product was digested using the restriction enzymes $\mathrm{NdeI}$ and SacI and cloned into pET-22b(+) to obtain the pETflu plasmid. The amplification of the sequences that codify for the SP and the TU of Ag43 were conducted using the pETflu plasmid as a template. The SP sequence was amplified using the pet38F(26) and RfluBNE primers, and the TU sequence was amplified using the DfluKXB and RfluHind primers. Following PCR amplification, the SP sequence was digested using NdeI and EcoRI and cloned into pTrc99A2. Next, the TU sequence was cloned into this derivative plasmid using KpnI and HindIII to obtain the pAg43pol plasmid (Figure 1). Finally, the $b g l C$ gene was removed from the pAIDABglC plasmid using BglII and SacI. This gene was then gelpurified and cloned into pAg43pol to obtain the pAg43BglC plasmid (Figure 1).

\section{Whole-cell protease treatment and OMP purification}

Whole-cell trypsin treatment and outer membrane proteins (OMPs) purification of trypsin-treated and nontreated cell were performed as described elsewhere [13]. The OMPs were analyzed using $12 \%$ sodium dodecyl sulfate polyacrylamide gel electrophoresis (SDS-PAGE). The samples were mixed with $2 \mathrm{X}$ loading buffer, heated in boiling water for $5 \mathrm{~min}$, and subjected to electrophoresis.

\section{Culture conditions}

Batch fermentation of cellobiose (Sigma-Aldrich, MO, USA) with cells expressing the pAg43BglC system were conducted as described elsewhere [13] in mineral AM1 media [30] supplemented with $0.1 \mathrm{~g} / \mathrm{L}$ of citrate (J.T. Baker, Avantor Performance Materials, NJ, USA), 2 g/L of sodium acetate (J.T. Baker), $100 \mathrm{mg} / \mathrm{L}$ of Carbenicillin and $10 \mu \mathrm{M}$ isopropyl $\beta$-D-1-thiogalactopyranoside (IPTG, Sigma-Aldrich). Cultures were performed in 300-mL Fleakers mini-fermenters [31] containing $200 \mathrm{~mL}$ of media without aeration at a $\mathrm{pH}$ of 7 , a temperature of $37^{\circ} \mathrm{C}$ and a speed of $150 \mathrm{rpm}$. Automatic additions of $2 \mathrm{~N} \mathrm{KOH}$ preserved a constant $\mathrm{pH}$. Prior to fermentation and the SSF process, the cells were adapted to grow in minifermenters as described previously [13]. The adapted cells were stored in cryotubes containing glycerol ( $40 \%$ final) to a final volume of $1.4 \mathrm{~mL}$ at $-70^{\circ} \mathrm{C}$.

To perform the SSF process with Avicel (PH-101, Sigma-Aldrich), a culture tube with $3 \mathrm{~mL}$ of Luria Broth (LB; $5 \mathrm{~g} / \mathrm{L}$ yeast extract, $10 \mathrm{~g} / \mathrm{L}$ Bacto peptone and $5 \mathrm{~g} / \mathrm{L}$ $\mathrm{NaCl}), 100 \mu \mathrm{g} / \mathrm{mL}$ of Carbenicillin and $10 \mathrm{~g} / \mathrm{L}$ of glucose was seeded with a cryotube containing cells of $E$. coli MS04/pAg43BglC or E. coli MS04/pTrc99A2 adapted into mini-fermenters The cells were grown at $37^{\circ} \mathrm{C}$ and $300 \mathrm{rpm}$ for $4 \mathrm{~h}$. Subsequently, the cells were inoculated in $1 \mathrm{~L}$ mineral media with $50 \mathrm{~g} / \mathrm{L}$ of glucose and $100 \mathrm{mg} / \mathrm{L}$ of Carbenicillin at an initial $\mathrm{OD}_{600}$ of approximately 0.001 and grown in a 1-L fermenter (Applikon ADI 1010/ ADI 1025, Schiedam, The Netherlands) with an aeration rate of 0.1 vvm at a temperature of $37^{\circ} \mathrm{C}$, a $\mathrm{pH}$ of 7.0 (adjusted by the automatic addition of $2 \mathrm{~N} \mathrm{KOH}$ ) and a speed of $400 \mathrm{rpm}$ (using one Rushton Turbine with 6 blades). During the growth of E. coli MS04/pAg43BglC, the temperature was maintained at $30^{\circ} \mathrm{C}$ when the cells reached $0.5 \mathrm{OD}_{600}$. In our previous work employing the autotransporter AIDA-I [13], we found that induction with $100 \mu \mathrm{M}$ IPTG hindered cell growth in comparison to when $10 \mu \mathrm{M}$ IPTG was used. For this reason, $10 \mu \mathrm{M}$ IPTG was also used in mini-fermenter cultures with the autotransporter Ag43. However, during the experiments in 1-L fermenters, we found that when $20 \mu \mathrm{M}$ IPTG was used for induction the cells produced enough $\beta$ glucosidase activity to continue the SSF process. Hence, MS04/pAg43BglC and MS04/pTrc99A2 cells grown in the 1 -L fermenters were induced with $20 \mu \mathrm{M}$ IPTG. Both strains were allowed to grow until $5.5 \mathrm{OD}_{600}$ was reached, and then the cells were harvested by centrifugation at $4,000 \times g$ for $10 \mathrm{~min}$ at room temperature (RT). Finally, SSF was carried out in $300-\mathrm{mL}$ Fleakers containing $200 \mathrm{~mL}$ of $50 \mathrm{mM}$ ammonium phosphate buffer with $40 \mathrm{~g} / \mathrm{L}$ of Avicel, $0.2 \%$ Tween 80, $100 \mathrm{mg} / \mathrm{L}$ of Carbenicillin and $10 \mathrm{OD}_{600}$ of cells. SSF was performed at $45^{\circ} \mathrm{C}$, $150 \mathrm{rpm}$ and $\mathrm{pH} 6$ (adjusted by the automatic addition of $2 \mathrm{~N} \mathrm{KOH})$.

\section{Preparation of soluble BglC and enzyme assays}

The production of soluble BglC was carried out with $E$. coli BL21 (DE3) carrying the plasmid pNS6 [21]. The cells were grown overnight in flasks containing $50 \mathrm{~mL}$ of LB with $30 \mu \mathrm{g} / \mathrm{mL}$ of Kanamycin at $37^{\circ} \mathrm{C}$ and $300 \mathrm{rpm}$. Subsequently, the $50 \mathrm{~mL}$ overnight culture was used to inoculate $950 \mathrm{~mL}$ of $\mathrm{LB}$ with $30 \mu \mathrm{g} / \mathrm{mL}$ of Kanamycin, and the cells were grown at $37^{\circ} \mathrm{C}$ and $300 \mathrm{rpm}$. When the cells reached an $\mathrm{OD}_{600}$ of 0.5 , the incubation temperature was switched to $20^{\circ} \mathrm{C}$ and the cells were induced with $0.5 \mathrm{mM}$ IPTG. Next, the cells were allowed to grow until an $\mathrm{OD}_{600}$ of 2 and harvested by centrifugation for $10 \mathrm{~min}$ at $4,000 \times g$ and $4^{\circ} \mathrm{C}$. The cells were washed twice with $20 \mathrm{~mL}$ of $50 \mathrm{mM}$ phosphate buffer ( $\mathrm{pH} 7$ ), and the cell pellet was resuspended in $5 \mathrm{~mL}$ of $50 \mathrm{mM}$ phosphate buffer ( $\mathrm{pH} 7$ ). Finally, the cells were lysed by sonication, and the $E$. coli extract was recovered by centrifugation for $30 \mathrm{~min}$ at $13,400 \times g$ and $4^{\circ} \mathrm{C}$. The extract was used as the source of soluble BglC during SSF control experiments with $30 \mathrm{U} / \mathrm{g}$ Avicel. 
The commercial enzymes used during the SSF process were the cellulase cocktail Celluclast ${ }^{\bullet} 1.5$ L (SigmaAldrich) and the $\beta$-glucosidase cocktail NS50010 (kindly provided by Novozymes, Brazil). Celluclast ${ }^{\oplus} 1.5 \mathrm{~L}$ and NS50010 were used during SSF at a concentration of 15 FPU/g Avicel and $30 \mathrm{U} / \mathrm{g}$ Avicel, respectively. The cellulase activity of Celluclast ${ }^{\oplus} 1.5 \mathrm{~L}$ was measured using a filter paper substrate, and the $\beta$-glucosidase activity of NS50010 was measured using a $p$-nitrophenyl- $\beta$-d-glucopyranoside (pNPG; Sigma) substrate. The activities of the commercial cocktails were calculated using the protocols described by Wood and Bhat [32].

The activity of the cell surface-attached $\beta$-glucosidase was assayed using a pNPG substrate. During the assays, $1 \mathrm{~mL}$ of cells expressing the pAg43BglC system were recovered by centrifugation (in a microfuge at 9,300 $\times g$ for $2 \mathrm{~min}$ at RT) and resuspended in $1 \mathrm{~mL}$ of $50 \mathrm{mM}$ phosphate buffer ( $\mathrm{pH} 7$ ). Subsequently, $100 \mu \mathrm{L}$ of the resuspended cells were mixed with $630 \mu \mathrm{L}$ of the same buffer. Then, the cell suspension was allowed to equilibrate to the assay temperature for $5 \mathrm{~min}$. The reaction was initiated via the addition of $100 \mathrm{mM}$ pNPG $(20 \mu \mathrm{L})$, and, after $5 \mathrm{~min}$, the reaction was terminated by adding $2 \mathrm{M} \mathrm{Na}_{2} \mathrm{CO}_{3}(250 \mu \mathrm{L})$. The absorbance (at $400 \mathrm{~nm}$ ) was measured after the cells were centrifuged in a microfuge at $9,300 \times g$ for $2 \mathrm{~min}$ at RT, and the enzyme activity was calculated using the extinction coefficient for $p$-nitrophenol $\left(18.5 \mathrm{mM}^{-1}\right)$ [21]. One pNPGase unit was defined as the amount of BglC attached to the cells such that the formation of pNP is catalyzed at a rate of $1 \mu \mathrm{mol}$ per minute.

To measure the $\beta$-glucosidase activity of soluble BglC, $20 \mu \mathrm{L}$ of the enzyme solution was mixed with $710 \mu \mathrm{L}$ of $50 \mathrm{mM}$ phosphate buffer $(\mathrm{pH} 7)$ and allowed to equilibrate to the assay temperature for $5 \mathrm{~min}$. The reaction was initiated via the addition of $20 \mu \mathrm{L}$ pNPG (100 mM), and, after $10 \mathrm{~min}$, the reaction was terminated by adding $250 \mu \mathrm{L}$ $\mathrm{Na}_{2} \mathrm{CO}_{3}(2 \mathrm{M})$. The absorbance (at $400 \mathrm{~nm}$ ) was measured, and the enzyme activity was calculated using the extinction coefficient for $p$-nitrophenol $\left(18.5 \mathrm{mM}^{-1}\right)$ [21]. One pNPGase unit was defined as the amount of BglC necessary to catalyze the formation of $\mathrm{pNP}$ at a rate of $1 \mu \mathrm{mol}$ per minute. To measure the $\beta$-glucosidase activity present in the milieu of $E$. coli expressing the Ag43-BglC system, $4 \mathrm{~mL}$ of the supernatant was passed through a centrifugal filter unit (Amicon Ultra-4, Millipore Corporation, MA, USA) with a $10 \mathrm{kDa}$ molecular weight cut-off. The $\beta$ glucosidase present in the supernatant was washed twice through the filter unit with $4 \mathrm{~mL}$ of $50 \mathrm{mM}$ phosphate buffer $(\mathrm{pH} \mathrm{7)}$ to remove any unutilized cellobiose, which can interfere with the interaction of BglC with pNPG. Subsequently, the supernatant was concentrated in the filter unit to a volume of approximately $0.5 \mathrm{~mL}$, and the activity was measured as already described.

\section{Analyses}

Growth was analyzed spectrophotometrically as the optical density at $600 \mathrm{~nm}$ (DU-70, Beckman Instruments Inc., CA, USA) and converted to dry cell weight (DCW) per liter using a calibration curve ( 1 optical density $\left.=0.37 \mathrm{~g}_{\mathrm{DCW}} / \mathrm{L}\right)$. The samples were centrifuged, and the cell-free culture broth was frozen until it was analyzed. The concentration of glucose was measured with an enzymatic analyzer (Model 2700, YSI Inc., OH, USA), whereas the cellobiose concentration was measured using the 3,5-dinitrosalicylic acid (DNS) method as described by Miller [33]. The ethanol was analyzed by gas chromatography using n-butanol as the internal standard (6850 Series GC System, Agilent, DE, USA). The concentrations of the cell biomass, ethanol and sugars were corrected for fermentation volume changes caused by the addition of base during culture.

Specific growth rates $(\mu)$ were calculated as the slopes of the linear regressions of the natural log of the cell mass versus time during the exponential growth phase. The ethanol yield (g ethanol/g carbon source) was estimated as a percentage of the theoretical maximum, taking into account that the theoretical yields obtained with glucose and cellobiose were 0.51 and 0.54 , respectively. All cultures and enzyme assays were carried out at least in triplicate (the averages and standard deviations are shown in plots and tables).

\section{Competing interests}

The authors declare that they have no competing interests.

\section{Authors' contributions}

IMG and AM participated in the design of this study. IMG constructed the plasmids and strains and performed the experimental work. CMA and BTM supported the development of cultures in mini-fermenters and the measurement of some enzymatic activities. IMG and AM analyzed the experimental data. IMG, GG and AM participated in the analysis of the results as well as in the writing and review of the manuscript. All authors have read and approved this manuscript.

\section{Acknowledgments}

We thank Dr. Jaime Ortega-López (Departamento de Biotecnología y Bioingeniería, CINVESTAV, México) for helpful discussions and Mercedes Enzaldo-Cruz and Georgina Hernández-Chávez for technical support. IMG was supported by a fellowship from CONACyT-México. The enzymatic preparation NS50010 was kindly provided by Novozymes Brazil.

\section{Author details}

'Departamento de Ingeniería Celular y Biocatálisis, Instituto de Biotecnología, Universidad Nacional Autónoma de México, A. P. 510-3, 62250 Cuernavaca, Mor, México. ${ }^{2}$ Present address: Department of Molecular Microbiology and Biotechnology, George S. Wise Faculty of Life Sciences, Tel Aviv University, Tel Aviv, Israel.

Received: 19 May 2014 Accepted: 14 July 2014

Published: 1 August 2014

\section{References}

1. Caspeta L, Buijs NAA, Nielsen J: The role of biofuels in the future energy supply. Energy Environ Sci 2013, 6:1077-1082.

2. Cardona CA, Sánchez OJ: Fuel ethanol production: process design trends and integration opportunities. Bioresour Technol 2007, 98:2415-2457. 
3. Olofsson K, Bertilsson M, Lidén G: A short review on SSF - an interesting process option for ethanol production from lignocellulosic feedstocks. Biotechnol Biofuels 2008, 1:7

4. Castro E: Other Ethanologenic Microorganism. In Lignocellul Convers. Edited by Faraco V. Berlin, Heidelberg: Springer-Verlag; 2013:152-168.

5. Fernández-Sandoval MT, Huerta-Beristain G, Trujillo-Martinez B, Bustos P, González V, Bolivar F, Gosset G, Martinez A: Laboratory metabolic evolution improves acetate tolerance and growth on acetate of ethanologenic Escherichia coli under non-aerated conditions in glucose-mineral medium. Appl Microbiol Biotechnol 2012, 96:1291-1300.

6. Wang X, Yomano LP, Lee JY, York SW, Zheng H, Mullinnix MT, Shanmugam $K T$, Ingram LO: Engineering furfural tolerance in Escherichia coli improves the fermentation of lignocellulosic sugars into renewable chemicals. Proc Natl Acad Sci U S A 2013, 110:4021-4026.

7. Edwards MC, Henriksen ED, Yomano LP, Gardner BC, Sharma LN, Ingram LO, Doran Peterson J: Addition of genes for cellobiase and pectinolytic activity in Escherichia coli for fuel ethanol production from pectin-rich lignocellulosic biomass. Appl Environ Microbiol 2011, 77:5184-5191.

8. Merino ST, Cherry J: Progress and challenges in enzyme development for biomass utilization. Adv Biochem Eng Biotechnol 2007, 108:95-120.

9. Moss-Acosta C, Trujillo-Martinez B, Orencio-Trejo M, Martinez-Jimenez A Sequential thermochemical hydrolysis, enzymatic saccharification and fermentation to ethanol of stover from white corn with ethanologenic bacteria. In 35th Symp Biotechnol Fuels Chem Soc Ind Microbiol. Portland, Oregon: EUA; 2013.

10. Muñoz-Gutiérrez I, Martinez A: Polysaccharide hydrolysis with engineered Escherichia coli for the production of biocommodities. J Ind Microbiol Biotechnol 2013, 40:401-410.

11. Nicolay T, Vanderleyden J, Spaepen S: Autotransporter-based cell surface display in Gram-negative bacteria. Crit Rev Microbiol 2013, 7828:1-15.

12. Leyton $\mathrm{DL}$, Rossiter $A E$, Henderson IR: From self sufficiency to dependence: mechanisms and factors important for autotransporter biogenesis. Nat Rev Microbiol 2012, 10:213-225.

13. Muñoz-Gutiérrez I, Oropeza R, Gosset G, Martinez A: Cell surface display of a $\beta$-glucosidase employing the type $V$ secretion system on ethanologenic Escherichia coli for the fermentation of cellobiose to ethanol. J Ind Microbiol Biotechnol 2012, 39:1141-1152.

14. Wargacki AJ, Leonard E, Win MN, Regitsky DD, Santos CNS, Kim PB, Cooper SR, Raisner RM, Herman A, Sivitz AB, Lakshmanaswamy A, Kashiyama Y, Baker D, Yoshikuni Y: An engineered microbial platform for direct biofuel production from brown macroalgae. Science 2012, 335:308-313.

15. Gustavsson M, Bäcklund E, Larsson G: Optimisation of surface expression using the AIDA autotransporter. Microb Cell Fact 2011, 10:72

16. Maurer J, Jose J, Meyer TF: Autodisplay: one-component system for efficient surface display and release of soluble recombinant proteins from Escherichia coli. J Bacteriol 1997, 179:794-804.

17. Ramesh B, Sendra VG, Cirino PC, Varadarajan N: Single-cell characterization of autotransporter-mediated Escherichia coli surface display of disulfide bond-containing proteins. J Biol Chem 2012, 287:38580-38589.

18. Kjaergaard K, Hasman H, Schembri MA, Klemm P: Antigen 43-mediated autotransporter display, a versatile bacterial cell surface presentation system. J Bacteriol 2002, 184:4197-4204.

19. Wells TJ, Totsika M, Schembri MA: Autotransporters of Escherichia coli: a sequence-based characterization. Microbiology 2010, 156:2459-2469.

20. Van der Woude MW, Henderson IR: Regulation and function of Ag43 (flu). Annu Rev Microbiol 2008, 62:153-169.

21. Spiridonov NA, Wilson DB: Cloning and biochemical characterization of BglC, a $\beta$-glucosidase from the cellulolytic actinomycete Thermobifida fusca. Curr Microbiol 2001, 42:295-301.

22. Desai SH, Rabinovitch-Deere CA, Tashiro Y, Atsumi S: Isobutanol production from cellobiose in Escherichia coli. Appl Microbiol Biotechnol 2014, 98:3727-3736

23. Soma Y, Inokuma K, Tanaka T, Ogino C, Kondo A, Okamoto M, Hanai T: Direct isopropanol production from cellobiose by engineered Escherichia coli using a synthetic pathway and a cell surface display system. J Biosci Bioeng 2012, 114:80-85.

24. Tanaka T, Kawabata H, Ogino C, Kondo A: Creation of a cellooligosaccharide-assimilating Escherichia coli strain by displaying active beta-glucosidase on the cell surface via a novel anchor protein Appl Environ Microbiol 2011, 77:6265-6270.
25. Henderson IR, Owen P: The major phase-variable outer membrane protein of Escherichia coli structurally resembles the immunoglobulin A1 protease class of exported protein and is regulated by a novel mechanism involving Dam and OxyR. J Bacteriol 1999, 181:2132-2141.

26. Seidle HF, Marten I, Shoseyov O, Huber RE: Physical and kinetic properties of the family $3 \beta$-glucosidase from Aspergillus niger which is important for cellulose breakdown. Protein J 2004, 23:11-23.

27. Calsavara LP, De Moraes FF, Zanin GM: Comparison of catalytic properties of free and immobilized cellobiase novozym 188. Appl Biochem Biotechnol 2001, 91-93:615-626.

28. Utrilla J, Licona-Cassani C, Marcellin E, Gosset G, Nielsen LK, Martinez A Engineering and adaptive evolution of Escherichia coli for D-lactate fermentation reveals GatC as a xylose transporter. Metab Eng 2012, 14:469-476

29. Sambrook J, Rusell D: Molecular Cloning a Laboratory Manual. 3rd edition. Cold Spring Harbor, New York: Cold Spring Harbor Laboratory Press; 2001.

30. Martinez A, Grabar TB, Shanmugam KT, Yomano LP, York SW, Ingram LO: Low salt medium for lactate and ethanol production by recombinant Escherichia coli B. Biotechnol Lett 2007, 29:397-404.

31. Beall DS, Ohta K, Ingram LO: Parametric studies of ethanol production form xylose and other sugars by recombinant Escherichia coli. Biotechnol Bioeng 1991, 38:296-303.

32. Wood T, Bhat K: Methods for measuring cellulase activities. Methods Enzymol 1988, 160:87-112.

33. Miller $G L$ : Use of dinitrosalicylic acid reagent for determination of reducing sugar. Anal Chem 1959, 31:426-428.

doi:10.1186/s12934-014-0106-3

Cite this article as: Muñoz-Gutiérrez et al:: Ag43-mediated display of a thermostable $\beta$-glucosidase in Escherichia coli and its use for simultaneous saccharification and fermentation at high temperatures. Microbial Cell Factories 2014 13:106.

\section{Submit your next manuscript to BioMed Central and take full advantage of:}

- Convenient online submission

- Thorough peer review

- No space constraints or color figure charges

- Immediate publication on acceptance

- Inclusion in PubMed, CAS, Scopus and Google Scholar

- Research which is freely available for redistribution
C Biomed Central 